\title{
THE INFLUENCE OF ORGANIZATIONAL CULTURE AND ORGANIZATIONAL COMMITMENT ON EMPLOYEE PERFORMANCE ORGANIZATIONAL CITIZENSHIP BEHAVIOR: A STUDY AT THE PUBLIC RELATIONS AND PROTOCOL BUREAU OF THE REGIONAL SECRETARY OF EAST JAVA PROVINCE, INDONESIA
}

\author{
Palupi Dini Dyah*, Masyur Arismunandar, Fitrian Rizal, Syamsudin Achmad, \\ Rahmawati Farida Yuni, Students \\ Master's Study Program of Management, University Bhayangkara Surabaya, Indonesia \\ *E-mail: dinidyahpalupi@gmail.com
}

\begin{abstract}
The success of the Public Relations and Protocol Bureau of the Regional Secretariat of East Java Province requires employees who can do work that exceeds standard work or whose performance exceeds the expectations of the organization. Performance requires a behavior such as organizational citizenship behavior (OCB) in service delivery. OCB is individual behavior in the workplace that can smooth employee performance. OCB is influenced by organizational culture and organizational commitment. The research objective is to analyze and prove the influence of organizational culture, organizational commitment on employee performance mediated by OCB. This type of research is explanatory with a saturated sampling technique. The employees of the Public Relations and Protocol Bureau of the Regional Secretariat of East Java Province as members of the population of 73 people, the sampling technique used are a saturated sample, so that all members of the population are the research subjects. Data analysis done by using path analysis method. Based on the research results it can be concluded; (1) the influence of organizational culture on OCB is 0.344 , (2) the influence of organizational commitment on OCB is 0.380 (3) the influence of OCB on employee performance is 0.34 (4) the influence of organizational culture on employee performance is 0.542 (5) the influence of organizational commitment on performance Employees are 0.157 (6) the influence of organizational culture on employee performance through OCB is 0.117 and the total influence is 0.659 (7) the effect of organizational commitment on employee performance through OCB is 0.157 and the total influence is 0.286 .
\end{abstract}

\section{KEY WORDS}

Organizational culture, organizational commitment, employee, performance.

In this era, the Public Relations and Protocol Bureau was considered a necessity that must exist in an institution or organization in order to build relationships with the community and stakeholders (Stakeholders). Public relations (PR) has been known and practiced for centuries. In essence, PR is always concerned with the creation of understanding through knowledge, and through these activities it is hoped that an impact will emerge, namely positive change.

Employees are a resource needed by an organization such as the Public Relations and Protocol Bureau of East Java Province. Employees play an active role in organizational processes and decision-making processes (Sutrisno, 2012: 2). The success of the Bureau of Public Relations and Protocol of East Java Province requires employees who can perform work exceeding standard work or performance exceeding organizational expectations. Such as helping colleagues in their work, not complaining about small things at work, and maintaining equipment owned by the Public Relations and Protocol Bureau. This kind of behavior is important for the Public Relations and Protocol Bureau considering that this bureau is in charge of serving the Governor's activities and bridging the relationship between the provincial government and the community, so that it requires speed and dexterity of employees and working together, helping each other so that work is done effectively and efficiently. 
Performance requires a behavior like OCB in service delivery. The results of observations at the Public Relations and Protocol Bureau are that there are still employees who are more concerned with personal matters than their work, there are still employees who do not like to cooperate with one another because the work demands of each employee are different, and there are still employees who do not innovate in their work so that there are no updates to the process or its work. In addition, there are employees who spend excessive time resting and are reluctant to take the time to help other employees with work problems. Low OCB means lower employee performance. This is also evidenced by the results of research by Gosaria and Setiawan (2014) and Lubis (2015). In general, employees who have high OCB can affect the performance of the employees concerned.

OCB is influenced by several factors including personality, organizational culture, organizational climate, job satisfaction, organizational commitment, transformational leadership \& servant leadership, employee social responsibility, employee age, work involvement, collectivism and organizational justice (Wirawan in Hendrawan et al, 2017) . One important factor is organizational culture. Culture serves to overcome the problems of internal integration by increasing the understanding and ability of organizational members to speak, communicate, internal agreement or consensus, power and rules, relationships of organizational members (employees) and rewards and sanctions (Rini, et al, 2013: 72). Organizational culture aims to change the attitudes and behavior of existing human resources in order to increase work productivity to face various challenges in the future. The benefits of implementing a good organizational culture are that it can increase the spirit of mutual cooperation, increase togetherness, open to one another, increase the spirit of kinship, increase a sense of kinship, build better communication, increase work productivity, be responsive to the development of the outside world, and so on. , most of which are part of the OCB.

Employees who support the organization have the potential to improve their capabilities within individuals, groups and organizations. Employees who have a high organizational commitment will support the company for the progress of the organization. In fact, Ghosaria's research (2014) shows that highly committed employees will be responsible for all their work and feel they belong to the organization. Organizational commitment also plays an important role in improving employee OCB.

\section{LITERATURE REVIEW}

Organizational culture is a system of values, beliefs, assumptions, or norms that have long been valid, agreed upon and followed by members of an organization as behavior guidelines and problem solving. Organizational problems (Sutrisno, 2012: 2), which appear in: (1) professionalism; (2) distance from management; (3) trust in colleagues; (4) regularity and (5) integration. Organizational commitment is the willingness to work harder to achieve organizational goals and have a greater desire to continue working in a company (Kreitner and Kinicki in Bukit and Rahmat, 2017: 27). The level of organizational commitment of an employee in aspects (1) affective, (2) sustainable and (3) normative in recognizing organization and organizational goals.

Organizational Citizenship Behavioral (OCB) is a helpful attitude shown by employees to the company, which is constructive in nature, appreciated by the company but not directly related to individual productivity (Organ, Podsakoff, and MacKenzie in Gosaria and Setiawan, 2014). This attitude can be seen in visible and observable employee volunteer behavior, such as: (1) Sportsmanship; (2) Civic Virtue; (3) Conscientiousness; (4) Altruism and (5) Courtesy.

Employee performance is the result of organizational work, which is done by employees as well as possible in accordance with the instructions (manual), directions given by the leader (manager), the competence and ability of employees to develop their reasoning at work (Abdullah, 2014: 3). According to Wirawan (Abdullah, 2014: 116-117) to measure performance indicators a criterion (size) is needed. The measure consists of (1) the result of the quantity of work; (2) work quality results; (3) timeliness; (4) attendance; and (5) the ability 
to work together as a result of work performance in accordance with its role in the organization. Based on the description of the study of the theory and the results of previous research, a conceptual framework can be made in Figure 1 as follows:

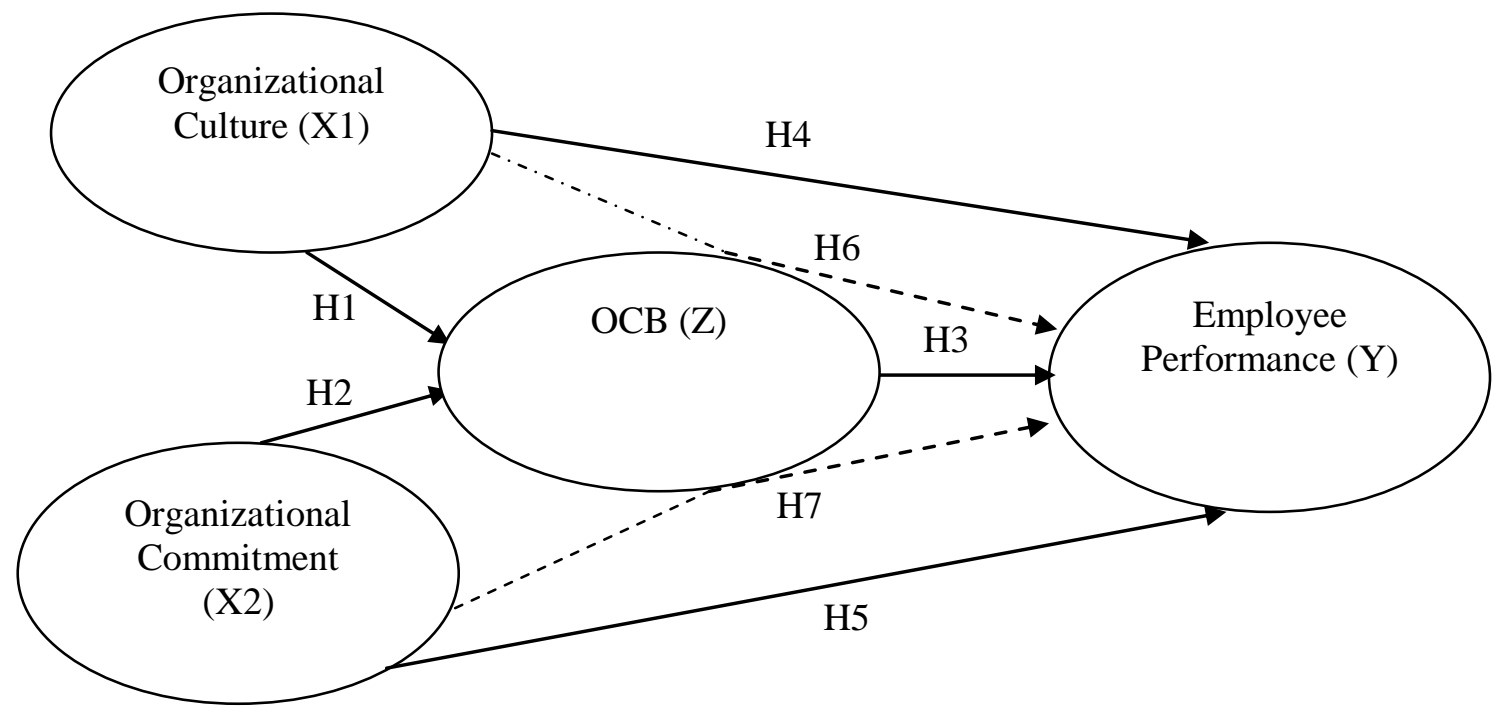

Figure 1 - Research Conceptual Framework

Based on the framework of thinking and conceptual framework, research hypotheses can be formulated: (1) Organizational culture has an effect on OCB, (2) Organizational commitment has an effect on OCB, (3) OCB has an effect on employee performance, (4) Organizational culture has an effect on employee performance, (4) 5) Organizational commitment affects employee performance, (6) Organizational culture affects performance through OCB and (7) Organizational commitment affects performance through OCB.

\section{METHODS OF RESEARCH}

This research is a type of Explanatory Research. Namely research that explains the influence between variables or hypotheses whose descriptions are associative, namely research that aims to determine the effect between two or more variables (Sugiyono, 2014: 11). This type of research is used in analyzing the influence of the independent variables, namely organizational culture and organizational commitment, the intervening variable, namely Organizational Citizenship Behavior (OCB) with employee performance as the dependent variable.

The population in this study was employees of the Public Relations and Protocol Bureau of East Java Province who worked for more than two years, with a total of 73 people consisting of 40 men and 33 women. Therefore, the sampling technique is Nonprobability sampling using Saturated Samples. The meaning of saturated samples is a technique of determining the sample by taking all members of the population as respondents or samples (Sugiyono, 2014: 124) The variables in this study consist of: exogenous variables, namely Organizational Culture (X1) and Organizational Commitment (X2), Intervening Variables: OCB (Z) and Endogenous Variables of Employee Performance, (Y).

Data sourced from primary data, namely data collected by researchers directly from the first source. With the data collection method, namely a questionnaire with answers using a linkert scale. Answers consist of five categories, Strongly Disagree (STS), Disagree (TS), Neutral, Agree (S) and Strongly Agree (SS) with a score of 1 to 5 . Hypothesis testing in the form of relationships and determining the number and magnitude of the influence of exogenous and endogenous variables uses linear regression-based path analysis techniques with the help of the SPSS R 21.0 application. 


\section{RESULTS OF STUDY}

The validity test is used to measure whether a questionnaire is valid or not. And reliability is an index number that shows the consistency of a measuring device in measuring the same symptoms. The results of the validity test obtained the value of each indicator variable probability value $(\mathrm{sig})=0,000(0,000<0.05)$, because sig $<0.05$, each indicator on the variable was declared valid. So that the questionnaire from these variables is valid and can be used for further research. While the questionnaire of these variables is reliable, because the Cronbach Alpha value of all variables shows greater than 0.6 (Ghozali, 2013: 49) and can be used for further research.

Hypothesis testing can be done if prerequisite testing is carried out. The prerequisite tests carried out were the normality test, multicollinearity test and heteroscedasticity test. The results meet the requirements set so that they are suitable for further analysis. Tests to prove the independent variables, namely organizational culture and organizational commitment, the intervening variable, namely Organizational Citizenship Behavior (OCB) with employee performance as the dependent variable.

Direct Effect. Hypothesis testing to prove the effect of $X 1$ and $X 2$ on $Z$, and from $X 1, X 2$ and $Z$ to $Y$, with multiple regression calculations the results:

Table 1 - Summary of Multiple Regression Analysis Results

\begin{tabular}{|l|l|l|l|l|}
\hline No & Hypothesis & Sig & Value $\alpha$ & Information \\
\hline 1 & $\begin{array}{l}\text { The Influence of Organizational Culture (X1) on } \\
\text { Organizational Citizenship Behavior (Z) }\end{array}$ & 0,028 & 0,05 & $\begin{array}{l}P_{\text {value }} \leq \alpha=\mathrm{H}_{0} \text { rejected and } \mathrm{H}_{1} \\
\text { accepted }\end{array}$ \\
\hline 2 & $\begin{array}{l}\text { Effect of Organizational Commitment }(\mathrm{X} 2) \text { on } \\
\text { Organizational citizenship behavior }(\mathrm{Z})\end{array}$ & 0,016 & 0,05 & $\begin{array}{l}\mathrm{P}_{\text {value }} \leq \alpha=\mathrm{H}_{0} \text { rejected and } \mathrm{H}_{1} \\
\text { accepted }\end{array}$ \\
\hline 3 & $\begin{array}{l}\text { Effects of Organizational Citizenship behavior }(\mathrm{Z}) \text { towards } \\
\text { employee performance }(\mathrm{Y})\end{array}$ & 0,000 & 0,05 & $\begin{array}{l}\mathrm{P}_{\text {value }} \leq \alpha=\mathrm{H}_{0} \text { rejected and } \mathrm{H}_{1} \\
\text { accepted }\end{array}$ \\
\hline 4 & $\begin{array}{l}\text { The Influence of Organizational Culture }(\mathrm{X} 1) \text { on employee } \\
\text { performance }(\mathrm{Y})\end{array}$ & 0,000 & 0,05 & $\begin{array}{l}\text { Pvalue } \leq \alpha=\mathrm{H}_{0} \text { rejected and } \mathrm{H}_{1} \\
\text { accepted }\end{array}$ \\
\hline 5 & $\begin{array}{l}\text { The Influence of Organizational Commitment }(\mathrm{X} 2) \text { on } \\
\text { employee performance }(\mathrm{Y})\end{array}$ & 0,039 & 0,05 & $\begin{array}{l}\mathrm{P}_{\text {value }} \leq \alpha=\mathrm{H}_{0} \text { rejected and } \mathrm{H}_{1} \\
\text { accepted }\end{array}$ \\
\hline
\end{tabular}

Source: Primary Data Processed in 2020.

Table 1 shows Hypothesis 1 to hypothesis 5 stated that "there is a significant influence, indicated that the $p$-value is smaller than the significant level $\alpha=5 \%$, then $\mathrm{H} 0$ is rejected. $\mathrm{H} 1$ is accepted, which means that there is a significant effect. To determine the path as shown in Figure 1, the path coefficient is calculated based on the per-structure equation.

Table 2 - Organizational Culture (X1) and Organizational Commitment (X2) to Organizational Citizenship Behavior (OCB) (Z)

\begin{tabular}{|l|l|l|l|l|}
\hline Model & R & R Square & Adjusted R Square & Std. Error of the Estimate \\
\hline 1 &, $692^{\mathrm{a}}$ &, 478 &, 463 & 3,861 \\
\hline \multicolumn{2}{|l|}{ a. Predictors: (Constant), Organizational Commitment, Organizational Culture. } \\
\hline
\end{tabular}

Source: Primary Data Processed in 2020.

From Table 2 it can be explained that the value of the coefficient of determination is the ability of the $X 1$ and $X 2$ variables to explain the $Y$ variable. The $R 2$ or $R 2 Z \times 2 \times 1$ value is 0.478 . This means that $47.8 \%$ of the Organizational Citizenship Behavior (OCB) $(Z)$ variable can be explained by organizational culture variables $(\mathrm{X} 1)$ and organizational commitment (X2). So that the rest (error) is influenced by other variables which are factors that are not in this study, thus the error $(z 1)$ is $\sqrt{ } 1-R=\sqrt{ } 1-0.478=\sqrt{ } 0.522=0,7224$.

From table 3 , it is used to see the results of the overall test regarding whether or not there is a linear relationship between exogenous variables and endogenous variables. Ho is rejected if the $p$-value $<0,05$. From the table it is obtained Fo $=32.088$; df $1=2$; df $2=70$, $p$ value $=0.000<0.05$ or $\mathrm{Ho}$ is rejected. Based on the results of the analysis in the table above, thus, the variable organizational culture (X1) and organizational commitment (X2) to 
organizational citizenship behavior (OCB) (Z) simultaneously have a significant effect.

Table 3 - The Coefficient of Determination of Organizational Culture (X1) and Organizational Commitment (X2) to Organizational Citizenship Behavior (Z)

ANOVAa

\begin{tabular}{|l|l|l|l|l|l|}
\hline Model & Sum of Squares & df & Mean Square & $F$ & Sig. \\
\hline Regression & 956,615 & 2 & 478,307 & & \\
$\begin{aligned} 1 \\
\text { Residual }\end{aligned}$ & 1043,413 & 70 & 14,906 & 32,088 &, $000 \mathrm{~b}$ \\
\hline Total & 2000,027 & 72 & & & \\
\hline
\end{tabular}

Source: Primary Data Processed in 2020.

Table 4 - Organizational Culture Path Coefficient (X1) and Organizational Commitment (X2) to Organizational Citizenship Behavior (Z)

Coefficients $^{\mathrm{a}}$

\begin{tabular}{|l|l|l|l|l|l|}
\hline \multirow{2}{*}{ Model } & Unstandardized Coefficients & Standardized Coefficients & t & Sig. \\
\cline { 2 - 6 } & $\mathrm{B}$ & Std. Error & Beta & 7,810 &, 000 \\
\hline (Constant) & 21,350 & 2,734 & & 2,240 &, 028 \\
1 Organizational culture &, 264 &, 118 &, 344 & 2,477 \\
Organizational commitment &, 459 &, 185 &, 380 &, 016 \\
\hline
\end{tabular}

Source: Primary Data Processed in 2020.

In Table 4 above, you can see the path coefficient values in the standardized coefficients (Beta) column. So that the following equation is obtained: $Z=0.344 X 1+0.380$ $\mathrm{X} 2+\varepsilon 1$. The interpretation of this equation is that the coefficient value for variable $\mathrm{X} 1$ is 0.344. This implies that every one-unit increase in organizational culture, the Organizational Citizenship Behavior (OCB) variable will increase by 0.344 with the assumption that the other independent variables of the above model are fixed. Similarly, the value of the coefficient of organizational commitment for variable $\mathrm{X} 2$ is 0.308 . This implies that every one unit increase in organizational commitment, the OCB variable will increase by 0.380 with the assumption that the other independent variables from the above model are fixed. Structural 2: Organizational Culture (X1), Organizational Commitment (X2) and OCB (Z) on Employee Performance $(Y)$ to measure the coefficient of determination in the linear regression calculation, the two OCB variables are positioned as independent variables, the results are as follows.

Table 5 - Coefficient of Determination of Organizational Culture (X1), Organizational Commitment

(X2) and Organizational Citizenship Behavior (OCB) (Z) on Employee Performance (Y)

Model Summary

\begin{tabular}{|l|l|l|l|l|}
\hline Model & $\mathrm{R}$ & $\mathrm{R}$ Square & Adjusted R Square & Std. Error of the Estimate \\
\hline 1 &, $942^{\mathrm{a}}$ &, 888 &, 883 & 1,946 \\
\hline
\end{tabular}

Source: Primary Data Processed in 2020.

Based on Table 5, it can be explained that the value of the coefficient of determination is the ability of the variables $X 1, X 2$ and $Z$ to explain the $Y$ variable. The value of $R 2$ or $\mathrm{R} 2 \mathrm{zx} 2 \times 1$ is 0.888 . This means that $88.8 \%$ of the employee performance variable $(\mathrm{Y})$ can be explained by the organizational culture (X1), organizational commitment (X2) and OCB (Z) variables. So that the rest (error) is influenced by other variables which are factors that are not in this study, thus the error $(z 2)$ is $\sqrt{ } 1-R=\sqrt{ } 1-0.888=\sqrt{ } 0.112=0,3347$.

Table 6 - Coefficient of Determination of Organizational Culture (X1), Organizational Commitment

(X2) and Organizational Citizenship Behavior (OCB) (Z) on Employee Performance (Y) ANOVA $^{\mathrm{a}}$

\begin{tabular}{|l|l|l|l|l|l|}
\hline Model & Sum of Squares & df & Mean Square & F & Sig. \\
\hline Regression & 2071,104 & 3 & 690,368 & & \\
1 Residual & 261,417 & 69 & 3,789 & 182,220 &, $000 \mathrm{~b}$ \\
$\quad$ Total & 2332,521 & 72 & & & \\
\hline
\end{tabular}

Source: Primary Data Processed in 2020. 
From table 6, it is used to see the results of the overall test whether there is a linear relationship between exogenous variables and endogenous variables. Ho is rejected if the $p$ value is $<0.05$. From the table, it is obtained Fo $=182,220$; df $1=2$; df2 $=69$, $p$-value $=0.000$ $<0.05$ or $\mathrm{Ho}$ is rejected. Based on the results of the analysis in the table above, the variables of organizational culture (X1), organizational commitment (X2) and Organizational Citizenship Behavior (OCB) (Z) on employee performance (Y) simultaneously have a significant effect.

Table 7 - Organizational Culture Path Coefficient (X1), Organizational Commitment (X2) and Organizational Citizenship Behavior (Z) on Employee Performance (Y)

Coefficients $^{\mathrm{a}}$

\begin{tabular}{|c|c|c|c|c|c|c|}
\hline \multirow{2}{*}{\multicolumn{2}{|c|}{ Model }} & \multicolumn{2}{|c|}{ Unstandardized Coefficients } & \multirow{2}{*}{$\begin{array}{l}\text { Standardized } \\
\text { Coefficients } \\
\text { Beta } \\
\end{array}$} & \multirow{2}{*}{$\mathrm{t}$} & \multirow{2}{*}{ Sig. } \\
\hline & & $\mathrm{B}$ & Std. Error & & & \\
\hline 1 & $\begin{array}{l}\text { (Constant) } \\
\text { Organizational culture } \\
\text { Organizational commitment } \\
\text { OCB }\end{array}$ & $\begin{array}{l}3,775 \\
, 450 \\
, 205 \\
, 367\end{array}$ & $\begin{array}{l}1,885 \\
, 062 \\
, 097 \\
, 060\end{array}$ & $\begin{array}{l}, 542 \\
, 157 \\
, 340\end{array}$ & $\begin{array}{l}2,002 \\
7,306 \\
2,108 \\
6,089\end{array}$ & $\begin{array}{l}, 049 \\
, 000 \\
, 039 \\
, 000\end{array}$ \\
\hline
\end{tabular}

Based on the table 5.20 above, it can be seen the path coefficient values in the standardized coefficients (Beta) column. So that the following equation is obtained: $Y=0.542$ $\mathrm{X} 1+0.157 \mathrm{X} 2+0.340 \mathrm{Z}+\varepsilon 2$. The interpretation of this equation is that the coefficient value for variable $\mathrm{X} 1$ is 0.542 . This implies that every one-unit increase in organizational culture, the employee performance variable will increase by 0.542 with the assumption that the other independent variables from the above model are fixed. Similarly, the value of the coefficient of organizational commitment for variable $\mathrm{X} 2$ is 0.157 . This implies that every one unit increase in organizational commitment, the employee performance variable will increase by 0.157 with the assumption that the other independent variables from the above model are fixed. Likewise, the Organizational Citizenship Behavior variable, each increase in Organizational Citizenship Behavior by one unit, the employee performance variable will increase by 0.340 assuming that the other independent variables from the above model are fixed.

Indirect Effect. The indirect effect on variables $\mathrm{X} 1$ (organizational culture), X2 (organizational commitment) affects $\mathrm{Y}$ (employee performance) through Organizational Citizenship Behavior (OCB) (Z), associated with hypotheses 6 and 7 . Based on Figure 1 above the one-way arrow (dashed line) indirect influence, namely the influence of organizational culture on performance through OCB and the effect of organizational commitment on performance through OCB. From these variables can be expressed in the form $=X 1->\mathrm{Z} \rightarrow \mathrm{Y}$ and $\mathrm{X} 2 \rightarrow \mathrm{Z} \rightarrow \mathrm{Y}$.

To test the mediation of a variable path, three regression tests are needed, namely (1) independent regression on the mediator, (2) independent on the dependent, and (3) independent and mediator on the dependent. Although in the causal step it is stated that there are conditions to prove a variable as intervening, but actually if the coefficient $a(X 1->Z)$ and $b(Z->Y)$ the influence is significant, this is enough to prove the existence of mediation. This is as expressed by Ghozali (2013: 114) argues that the determination of the intervening variable depends on its theoretical form, for example in the model $A->B->C$ where it is clear that the relationship $A$ to $C$ is not direct, must go through $B$, then if $A$ to $B$ is significant, and $B$ to $C$ is also significant, then $B$ is intervening and the relationship $A$ to $C$ does not pass directly through $B$. has been used to test the hypothesis of the direct relationship between variables, the results are summarized in table 5.21 where: (1) there is a significant influence on organizational culture (X1) on OCB $(Z),(2)$ there is a significant effect on organizational commitment (X2) on OCB ( $Z$ ) and (3) there is a significant effect of OCB (Z) on employee performance (Y) and based on Ghozali's opinion (2013: 114), it can be stated that hypotheses 6 and 7 have been shown to have a significant effect, so to find out the size the indirect and total effects of each variable can be explained as follows:

- The magnitude of the indirect effect coefficient $\left(X_{1} \rightarrow Z->Y\right)$ and $\left(X_{2} \rightarrow Z->Y\right)$ The 
indirect effect of $\mathrm{X} 1$ on $\mathrm{Y}$ through $\mathrm{Z}$ and $\mathrm{X} 2$ on $\mathrm{Y}$ through $\mathrm{Z}$ is obtained by multiplying the path coefficient. Mathematically that can be solved in the form of an equation as follows:

0 Indirect influence $X 1 \rightarrow Z \rightarrow Y=$ Beta value $(X 1 \rightarrow Z=$ direct influence of organizational culture on $O C B) X$ Beta value $(Z \rightarrow Y=$ direct influence of Organizational Citizenship Behavior (OCB)) on employee performance), namely $=(0.344) \times(0.340)=0.117$;

0 Indirect effect $X 2 \rightarrow Z \rightarrow Y=$ Beta value $(X 2 \rightarrow Z=$ direct effect of organizational commitment to OCB) $X$ Beta value $(Z->Y)=$ (direct effect of OCB on employee performance), namely $=(0.380) \times(0.340)=0.129$.

- The total coefficient of indirect effect $(X 1->Y)$ and $(X 2->Y)$ :

$\circ$ The total effect given by $X_{1} \rightarrow Y$ is the direct effect + indirect effect, = beta value (the influence of organizational culture on performance) + beta value (the influence of organizational culture on performance through OCB $=0.542$ $+0.117=0.659$;

○ The total effect given by $X 2->Y$ is the direct effect + the indirect effect, namely the beta value (the effect of organizational commitment on performance) + the beta value (the effect of organizational commitment on performance through OCB) $=0.157+0.129=0.286$.

\section{CONCLUSION}

Organizational culture has a positive and partially significant effect on organizational citizenship behavior (OCB) of employees of the Public Relations and Protocol Bureau of the Regional Secretariat of East Java Province.

Organizational commitment has a positive and partially significant effect on organizational citizenship behavior (OCB) of employees of the Public Relations and Protocol Bureau of the Regional Secretariat of East Java Province.

Organizational Citizenship Behavior (OCB) has a positive and partially significant effect on the performance of employees of the Public Relations and Protocol Bureau of the Regional Secretariat of East Java Province.

Organizational culture has a partially positive and significant effect on the performance of the employees of the Public Relations and Protocol Bureau of the Regional Secretariat of East Java Province.

Organizational commitment has a partially positive and significant effect on the performance of the employees of the Public Relations and Protocol Bureau of the Regional Secretariat of East Java Province.

Organizational culture has a positive and partially significant effect on the performance of the employees of the Public Relations and Protocol Bureau of the Regional Secretariat of East Java Province through organizational citizenship behavior (OCB).

Organizational commitment has a positive and partially significant effect on the performance of the employees of the Public Relations and Protocol Bureau of the Regional Secretariat of East Java Province through organizational citizenship behavior (OCB).

\section{REFERENCES}

1. Abdullah, M. Ma'ruf. 2014. Manajemen dan Evaluasi Kinerja Karyawan. Yogyakarta: Aswaja ressindo.

2. Bukit, Malusa dan Rahmat, 2017. Pengembangan Sumberdaya Manusia. Yogyakarta: Zahir.

3. Ghozali, Imam. 2013. Aplikasi Analisis Multivariate dengan Program IBM SPSS. 21 Update PLS Regresi. Semarang: Badan Penerbit Universitas. Diponegoro.

4. Gosaria, Danny Ch dan Setiawan, Roy. 2014. Pengaruh Leadership Member Exchange Dan Komitmen Organisasional Terhadap Organizational Citizenship Behavior Karyawan 
Di PT. WELCO. Jurnal AGORA Vol. 2, No. 1, (2014) http://publication.petra.ac.id/index.php/manajemen-bisnis/article/download/1441/1299 diakses 12 Maret 2020.

5. Hendrawan, Andi, Sucahyawati, Hari dan Indriyani. 2017. Organizational Citizenship Behavior (OCB) Pada Karyawan Akademi Maritim Nusantara. Prosideng seminar Nasional dan Internasional UNIMUS | Universitas Muhammadiyah Semarang hal 39-48 https://jurnal.unimus.ac.id/ index.php/psn12012010/article/view/2271 diakses 12 Maret 2020.

6. Lubis, M. Saleh. 2015. Pengaruh Iklim Organisasi Dan Komitmen Organisasi Terhadap Pembentukan Organizational Citizenship Behavior (OCB) Karyawan Dalam Rangka Peningkatan Kinerja. Universitas Muhammadiyah Semarang. https://journal.stiem.ac.id/index.php/jureq/ article/download/167/144 diakses 17 Maret 2020.

7. Rini, Dyah Puspita, Rusdarti dan Suparjo. 2013. "Pengaruh Komitmen Organisasi, Kepuasan Kerja Dan Budaya Organisasi Terhadap Organizational Citizenship Behavior (OCB) (Studi Pada PT. Plasa Simpanglima Semarang)". Jurnal IImiah Dinamika Ekonomi Dan Bisnis. Vol. 1 No. 1 April 2013. Semarang: Universitas 17 Agustus 1945. Hal. 69-88. http://jurnal.untagsmg.ac.id/index.php/jideb/article/view/255 diakses 17 Maret 2020

8. Sugiyono. 2014. Metode Penelitian Pendidikan Pendekatan Kuantitatif,. Kualitatif, dan R\&D. Bandung: Alfabeta.

9. Sutrisno, Edy. 2012. Manajemen Sumber Daya Manusia. Edisi 1. Cetakan Keempat. Jakarta: Prenada Media Group. 